\title{
Category of inclusiveness and evaluation: its correlation in scientific discourse
}

\author{
Ya. V. Bedrych \\ orcid.org/0000-0001-8634-3124 \\ Kyiv, Research and Educational Center for Foreign Languages, National Academy of Science of Ukraine \\ Corresponding author. E-mail: bedrych@ukr.net
}

Paper received 26.10.18; Accepted for publication 05.11.18.

\author{
https://doi.org/10.31174/SEND-Ph2018-183VI54-01
}

\begin{abstract}
The paper deals with the correlation of the category of inclusiveness and the category of evaluation. The category of inclusiveness denotes inclusion of parts into whole or that some whole consists of some part(s). The category of evaluation expresses speaker's positive, negative or neutral attitude to message. The category of evaluation in the light of the category of inclusiveness denotes full inclusion or non inclusion. The main inclusive evaluative lexical units are: adverbs (completely, totally, fully, mainly, generally, often, typically, usually), adjectives (multi-purpose, universal, all-purpose, all-encompassing, comprehensive, inclusive, all-inclusive) and negative lexical units (no, not, without).
\end{abstract}

Keywords: Scientific discourse, language of science, category of inclusiveness, category of evaluation, , information and communication technology.

Introduction. Recently, there has been growing interest in studying discourse, to be more exact, scientific discourse. There is a considerable amount of literature on this question, to name a few: Bazerman C. [15], Darian S. [20], Hyland K. [24], Swales J.M. [27], Ilchenko O.M. [6], and others. Besides, there are lots of papers that have studied different categories in scientific discourse, that is: Akulenko V.V. [8], Ilchenko O.M. [6], Volf T.M. [3], Kosmeda A.T. [9], Kravtsova O.O. [10], Shalya O.I. [14], and others. We've decided to study the category of inclusiveness, because we consider it as integral category of scientific discourse. Moreover, current corpus linguistics studies show that the verbs of inclusive semantics such as "to group," "to system," "to include," "to involve" are among the most frequently used words in 120 billion words COCA Academic vocabulary lists of English [21].

We have considered the category of inclusiveness as a cognitive-discursive category that is verbally (explicitly, semi-implicitly, implicitly) as well as visually expressed with various linguistic devices signaling inclusiveness. We have already studied implicit, stylistic, non-verbal and lexical ways of rendering the category of inclusiveness, its linguocultural potential as well as correlation with the category of quantity. In the present paper we want to study correlation of the category of inclusiveness with the category of evaluation.

The goal of the paper is to describe and classify some features of correlation between the category of inclusiveness and the category of evaluation. The subject of our investigation is the category of inclusiveness in Anglo-American scientific discourse.

Materials and methods. To do our research, we used the language material selected from Anglo-American articles in the field of information and communication technologies, such as The International Journal on Advances in Internet Technology (IJAIT) (2010-2015), The International Journal on Advances in Systems and Measurements (IJASM) (20102015), The International Journal on Advances in Intelligent Systems (IJAIS) (2010-2014), The International Journal on Advances in Networks and Services (IJANS) (2010-2015), IEEE Communications Magazine (CM) (2008-2014). Overall number of the articles is 1686 , or about 10 billion words. Dictionary definitions analysis, componential analysis and the method of opposition are used in our research.

A brief review of publications on the subject. Few attempts have been made to describe inclusiveness, but in aspects of another studies. Let's have a look on it in details. The core of the category of inclusiveness is the correlation "Part-Whole". First and foremost it was regarded by ancient philosophers Aristotel [1], Platon [2], Gusserl E. [4]. It's said that PART and WHOLE - are philosophical categories that express correlation between objects (or elements of other object) and connection, that unite these objects and create new (integrative) features. Lingual aspect of inclusiveness deals with inclusive (politically correct, gender neutral or non-sexist) language (Ter-Minasova [13], D’Souza D. [19], Jacobson C. [25], Ravitch D. [26], S. Walker [28]). Politically-correct language is used to describe all measures that are intended to avoid all stereotypes, which can touch members of particular groups of society. Inclusiveness also is associated with so called "pluralis auctoris" або "pluralis inclusivus", i.e. using of pronoun WE to denote speaker and the audience as one whole.

In pedagogies, inclusiveness has to do with "inclusive education", i.e. education of disabled people or people with physical or psychological illness in common schools, universities, etc. [12].

In linguistics there are also some studies that deal with inclusiveness. First of all, it's brilliant American linguist D.G. Greenberg. He has regarded the category of inclusiveness as well as the category of quantity as universal categories [23]. As a cognitive category, inclusiveness was studied in psycholinguistics as a tool for structuring and understanding cognition [17]. B.Berlin has claimed that the category of hierarchical inclusiveness presents different levels of reality [16]. Professor ZhabotynskaS. has considered inclusiveness (in her studying of lingual networks) in the context of inclusiveness-possessiveness [5]. In addition, US researchers have distinguished implicit, explicit and inclusive verbs. The latter one is used for description of connection among the elements of a whole [22].

The category of evaluation expresses speaker's positive, negative or neutral attitude to some message. It was studied by many researchers, such as: Volf T.M. [3], Kosmeda A.T. [9], Onyshchenko I.V. [11].

Results and discussion. While studying our empirical material, we have found different ways of correlation between the category of inclusiveness and the category of evaluation in scientific discourse. They are:

1. Adverbs completely, totally, fully are used to give positive evaluation to the inclusive verbs. In this case they denote full $(100 \%)$ inclusion of parts. Let's have a look on some examples:

The horizontal projection of the rectangle on any vertical line that intersects it must also be completely included in a segment of this line [IJASM, № 1-2, 2014, 83]. 
This article presents and compares two possible approaches to IP flow mobility offloading that are currently being considered by the IETF. The first one is based on extending existing client-based IP mobility solutions to allow flow mobility where the user terminal is fully involved in the mobility process [CM, October 2011, 124].

Both the IEEE 802.22-2011 downlink and uplink subframes have totally 60 subchannels, where each subchannel consists of 28 subcarriers out of which 24 data and 4 pilot subcarriers [CM, January 2014, 207].

So, there is full inclusion of parts (the horizontal projection of the rectangle, the user terminal) into whole (a segment of this line, the mobility process) in the first two sentences. While in the last one, some whole (both the IEEE 802.22-2011 downlink and uplink subframes) possess some parts $(60$ subchannels $)$. Nevertheless, all three sentences denote full inclusion.

2. Adverbs mainly, generally, often, typically, usually. These adverbs also denote full inclusion, but

implicitly. For instance:

The cost of maintaining the network mostly comprises replacement packs and the labor required to physically replace the failed packs in a shelf, which may be located anywhere in the network covering a given geographical area [CM, February 2010, 68].

The access network is the most expensive part of an operator's network and often comprises many different types of network equipment [CM, January 2014, 137].

The criteria are usually composed of a function that depends on the maximum likelihood estimator of the parameters of the model and a term that adjusts the first component to the context [IJANS, № 3-4 2012, 270].

A home network generally comprises a large number of different devices as well as distinct services, which maygenerate dramatically diverse data sources [CM, April 2011,45].

3. Adjectives: multi-purpose, universal, all-purpose, allencompassing, comprehensive. It should be stated

that adjectives are considered to be the main axiological unit, because they denote quality of a subject as well as give qualitative characteristics to the subject. Let's consider some examples from our empirical material:

Figure 1 shows various relay categories in three standards. 802.16j has the most comprehensive relay categories compared to the other standards [CM, August 2010, 40].

Adjective all-encompassing (including all or everything [29]) (composition of inclusive pronoun all and inclusive verb encompass) gives positive meaning to a noun (part) and characterize it as full, all, complex [7, p. 31]. For example:

The automated adaption supports workflow diversity, reducing complexity and maintenance compared to allencompassing models [IJAIS, № 3-4 2011, 171].

Synonyms of the adjective all-encompassing are the adjectives multi-purpose and universal, they also have the meaning to cover everything, [7, p. 31, 364, 571], for instance:

This topology is a popular multi-purpose configuration consisting of 3 routers, 3 switches and 3 virtual PCs [IJANS, № 3-4 2010, 374].

\section{ЛИТЕРАТУРА}

1. Аристотель Метафизика. Переводы. Комментарии; [сост. и подгот. текста С.И. Еремеев]. - СПб.: “Алетейя”, 2002. - 832 с.

2. Виндельбанд В. Платон; [пер. с нем. Александра Громбаха]. К.: “Зовништгоргвидав Украины”, 1993.- 200 с.
Often, adjective multi-purpose was used as a part of special terms:

MIME Multipurpose Internet Mail Extensions standard [IJAIT, № 1-2 2012, 49]. In this example, multi-purpose is used to denote some whole (standard) that include large numbers of parts (functions).

As a rule, adjective universal is used in the terms in the field of information and communications technologies, as in the following examples:

Universal Mobile Telecommunications System architecture [IJAIT, №1-2 2012, 54; CM, May 2009, 96], Universal Integrated Circuit Card [IJAIT, № 3-4 2012, 86], Universal Description Discovery and Integration [IJAIT, № 3-4 2011, 93], The Universal Agent [IJAT, № 3-4 2010, 160], universal resource identifier [CM, April 2010, 115], Evolved Universal Terrestrial Radio Access [CM, May 2010, 86].

4. Adjective inclusive expresses inclusiveness. We have found such definition of the word "inclusive". If a

price is inclusive, it includes all the charges connected with the goods or services offered. For example:

This concept of validitydates is used byothermessage types, too. It denotes a time span between the time indicated by Valid From and Valid To, bothinclusive [IJAIT, № 1-2 2014, 102].

We should mention well known all-inclusive resort, i.e. type of resort when transfer, hotel, food, some entertainment, etc. is included.

5. On the other hand, inclusive lexical units can give not only positive evaluation to a part or whole, but also

negative ones. Negative particle not belongs to this group. When not is joined with inclusive lexical units, it means that parts don't belong to whole. For instance:

To indicate to the HA that the message is associated with an MC in an EVDO network, it doesn't include an access technology extension in the message [CM, June 2009, 129].

Everyone participating in the exploratory evaluation was not involved in the project before and saw the device for the first time [IJAIS, № 1-2 2014, 443].

The Attributes field doesn't contain any privacy or security data that may expose a user's identity information [CM, December 2011, 80].

Negation can be expressed by lexical units no and without:

A spanning tree of a graph is defined as any set of connecting branches that connects every node to every other node without forming any closed paths or loops [IJAIS, № 3-4 2012, 281].

Using this approach is quite beneficial, since the design becomes very modular and the structure becomes quite robust and compact as no connectors are involved [IJANS, № 3-4 2011, 266].

Conclusions. In this paper we have studied ways of using inclusive and evaluative lexical units. We have outlined such types of evaluative lexical units in the context of the category of inclusiveness as: adverbs (completely, totally, fully, mainly, generally, often, typically, usually), adjectives (multipurpose, universal, all-purpose, all-encompassing, comprehensive, inclusive, all-inclusive) and negative lexical units (no, not, without). Our future work will focus on other discursive features of the category of inclusiveness in scientific discourse.

\footnotetext{
3. Вольф Е.М. Функциональная семантика оценки. - М.: Едиториал УРСС, 2002. $-280 \mathrm{c}$.

4. Гуссерль Э. Логические исследования. Т II. Ч.1: Исследования по феноменологии и теории познания; [пер. с нем. В.И. Молчанова]. - М.: “Академический Проект”, 2011. - 565.
} 
5. Жаботинська C.A. Посесивна конструкція і концептуальні трансформи / Мова. Людина. Світ: до 70-ти річчя проф. М.П. Кочергана. Збірник наукових статей / під ред. О.О. Тараненка. - К.: Видавничий центр КНЛУ, 2006. - С. 178-192.

6. Ільченко O.M. Етикетизація англо-американського наукового дискурсу: дис. на здобуття наук. ступеня доктора філол. наук: 10.02.04 "Германські мови"; Київськ. нац. ун-т. ім. Т. Шевченка. - К., 2002. $-421 \mathrm{c}$. Education, Journalism (English-Ukrainian-Russian Dictionary) Англо-українсько-російський словник міжнародної комунікації: наука, техніка, освіта, журналістика (за загальною редакцією к. філол. н., доц. Жалая В.Я.). - К.: Видавниче підприємство “ЕДЕЛЬВЕЙС”, 2014. - 632 с.

8. Категория количества в современных европейских языках; [В.В. Акуленко, С.А. Швачко, Е.И. Букреева и др.]. - К.: “Наукова Думка", 1990. - 284 с.

9. Космеда T.A. Аксіологічні аспекти прагмалінгвістики: формування і розвиток категорії оцінки. - Л.: ЛНУ ім. І. Франка, 2000. $-345 \mathrm{c}$.

10. Кравцуова О.О. Категорія суперлативності англійських прикметників: функціональні та дискурсивні аспекти: автореф дис. на здобуття наук. ступеня канд. філол. наук: спец. 10.02.04 "Германські мови"; Київ. нац. ун-т ім. Т. Шевченка. K., 2011. $-22 \mathrm{c}$.

11. Онищенко I.B. Категорія оцінки та засоби іï вираження в публіцистичних та інформаційних текстах: автореф. дис. на здобуття наук. ступеня канд. філол. наук: 10.02 .01 "Українська мова"; Дніпропетровський нац. ун-т. - Дніпротпетровськ, 2004. $-20 \mathrm{c}$.

12. Основи інклюзивної освіти: навчально-методичний посібник / [за заг. ред. Колупаєвої А.А.]. - К.: “А.С.К.”, 2012. - 308 с.

13. Тер-Минасова С.Г. Язык и межкультурная коммуникация. М.: "Слово”, 2000. - 264 с.

14. Шаля O.I. Категорія порівняння у мові науки: функціональні, когнітивно-дискурсивні та лінгвокультурні параметри (на матеріалі англо-американських статей у галузі електроніки): дис. на здобуття наук. ступеня канд. філол. наук: спец. 10.02.04 "Германські мови"; Київ. нац. ун-т імені Т. Шевченка. - К., 2011. $-260 \mathrm{c}$.
7. Ільченко O.M. International Communicaton: Science, Technology,

15. Bazerman $C$. Shaping written knowledge. - Madison: "the University of Wisconsin Press", 1981. - 270 p.

16. Berlin B. Ethnobiological classification: principles of categorization of plants and animals in traditional society. - Princeton, NJ: "Princeton University Press", 1992. - 335 p.

17. Bornstein M.H. The development of object categorization in young children: hierarchical inclusiveness, age, perceptual attribute, and group versus individual analyses/Marc H.Bornstein, Martha E. Arterberry/Developmental Psychology, 2010.-Vol. 3, № 46(2).P.350-365.

18. Collins English Dictionary: Complete and Unabridged [E. pecypc]. - $\left[5^{\text {th }}\right.$ ed.]. - Collins, 2016. - Режим доступу: http://www.collinsdictionary.com/

19. D'Souza D. Illiberal Education: the Politics of Race and Sex on Campus. - NY: "The Free Press", 1991. - 250 p.

20. Darian $S$. Understanding the language of science. - University of Texas Press, 2003. - 262 p.

21. Davies $M$. The Academic Vocabulary List: Corpus of contemporary American English. - [E. pecypc], 2012. -Режим доступу до сайту: http://www.academicvocabulary.info/

22. Frels K. A Typology of Verbs for Scholarly Writing / K. Frels, Anthony J. Onwuegbuzie, John R. Slate // Research in the Schools. - Sam Houston State University, 2010. - Vol.17, No.1.-P. xx-xxxi.

23. Greenberg J.H. Universals of human language; [associate ed. Charles Albert Ferguson, Edith A. Moravchik]. - [Volume 3. Word Structure].-Stanford: Stanford University Press, 1978.-470p.

24. Hyland $K$. Disciplinary discourses. Social interactions in academic writing. - University of Michigan press, 2004. - 232 p.

25. Jacobson C. Some Notes on Gender-Neutral Language [E. peсурс]. - Режим доступу: https://www2.stetson.edu /secure/history/hy10302/nongenderlang.html

26. Ravitch D. [E. pecypc]: офіційний сайт професора Діани Равіч. - Режим доступу до сайту: http://dianeravitch.com/

27. Swales J.M. English in academic and research settings. - Cambridge: Cambridge University Press, $1990 .-260 \mathrm{p}$.

28. Walker S. Hate Speech: The history of American Controversy. University of Nebraska Press, Lincoln and London, 1994. - 167 p.

29. WordNet 3.0 [E. pecypc]. - Princeton University: Farlex, 2003 2012. - Режим доступу: http://www.thefreedictionary.com/dictionary.htm

ДЖЕРЕЛА ІЛЮСТРАТИВНОГО МАТЕРІАЛУ

30. IEEE Communications Magazine (2008-2014). Retrieved from http://www.comsoc.org/

31. The International Journal on Advances in Intelligent Systems (2010-2014). $\quad$ Retrieved from http://www.iariajournals.org/intelligent_systems/index.html

32. The International Journal on Advances in Internet Technology (2010-2015). Retrieved from

\section{REFERENCES}

1. Aristotel Metaphisics. Translations. Comments. - SPb "Aleteya", 2002. -832 p.

2. Vindelband $V$. Platon [transl. from German A. Grombakh]. K.: "Zovnishggorrvidav of Ukraine", 1993. - $200 \mathrm{p}$.

3. Volf E.M. Functional semantics of evaluation. - M.: Editorial UPSS, 2002. -280 p.

4. Gusserl E. Logical researches.T II. P.1: Researches of phenomenology and cognition theory [transl. form German V.I. Molchanov]. M.: "Academic Project", 2011. - 565p.

5. Zhabotynska S.A. Possessive construction and conceptual transforms // Language. Human. World/ ed. O.O. Taranenko - K.: Edition center KNLU, 2006. - P. 178-192.

6. Ilchenko O.M. Etiquettization in Anglo-American Scientific Discourse: diss. for a doctoral degree in philology: speciality 10.02.04 - Germanic Languages. - Taras Shevchenko National University of Kyiv. - Kyiv, 2002. - 421 p.

7. Ільченко O.M. International Communicaton: Science, Technology, Education, Journalism (English-Ukrainian-Russian Dictionary): (ed. Zhalay V.Ya.). - K.: "EDELVEIS", 2014. - 632 p.

8. The category of quantity in modern European languages [V.V. Akulenko, S.A. Shavachko, E.I. Bukreeva]. - K.: "Naukova Dumka", 1990. - 284 p.

\section{http://www.iariajournals.org/internet_technology/index.html}

33. The International Journal on Advances in Networks and Services (2010-2015). Retrieved from http://www.iariajournals.org/networks_and_services/index.html

34. The International Journal on Advances in Systems and Measurements (2010-2015). Retrieved from http://www.iariajournals.org /systems_and_measurements/index.html

9. Kosmeda T.A. Axiological aspects of pragmalinguistics: formation and development of the category of evaluation. - L.: LNU named after I. Franko, 2000. -345 p.

10. Kravtsova O.O. The category of superlativity of English adjective: functional and discursive aspects: a thesis for a Candidate Degree in Philology, speciality 10.02.04 - Germanic Languages. - Kyiv Taras Shevchenko National University. - Kyiv, 2011. - 22 c.

11. Onushchenko I.V. the category og evaluation and the way of its rendering in op-ed and infirmatiove texts: a thesis for a Candidate Degree in Philology, speciality 10.02.01 - Ukrainian language. Dnipropetrovsk national university. - Dnipropetrovsk, 2004.-20 p.

12. Background of inclusive udecation: [ed. Kolupaeva A.A.]. - K.: "A.S.K.", 2012. - 308 p.

13. Ter-Minasova S.G. Language and cross-cultural communications. - M.: "Slovo", 2000. - 264 p.

14. Shalya O.I. The Category of Comparison in the Language of Science: Functional, Cognitive, Discursive and Cultural Aspects: A dissertation for a Candidate Degree in Philology, speciality 10.02.04 - Germanic Languages. - Taras Shevchenko National University of Kyiv. - Kyiv, 2011. - 260 p.

15. Bazerman C. Shaping written knowledge. - Madison: "the University of Wisconsin Press", 1981.-270 p. 